\title{
PERIKANAN TANGKAP DI INDONESIA: POTRET DAN TANTANGAN KEBERLANJUTANNYA
}

\author{
Capture Fisheries in Indonesia: \\ Portraits and Challenges of Sustainability
}

\author{
*Kusdiantoro', Achmad Fahrudin², Sugeng Hari Wisudo², dan Bambang Juanda' \\ ${ }^{1}$ Fakultas Ekonomi dan Manajemen, Institut Pertanian Bogor \\ Kampus IPB Darmaga, Jalan Agatis, Babakan, Dramaga, Kota Bogor, Jawa Barat, Indonesia \\ ${ }^{2}$ Fakultas Perikanan dan IImu Kelautan, Institut Pertanian Bogor \\ Kampus IPB Darmaga, Jalan Agatis, Babakan, Dramaga, Kota Bogor, Jawa Barat, Indonesia \\ Diterima tanggal: 2 Juli 2019 Diterima setelah perbaikan: 20 Oktober 2019 \\ Disetujui terbit: 10 Desember 2019
}

\begin{abstract}
ABSTRAK
Perikanan tangkap di Indonesia memiliki peran strategis, namun dalam pelaksanaannya tidak terlepas dari kompleksitasnya pemasalahan yang dihadapi. Ancaman terhadap keberlanjutan sumber daya ikan dan kapasitas pelaku usaha menjadi perhatian utama dalam mewujudkan perikanan tangkap berkelanjutan. Penelitian ini bertujuan unutk mengkaji kondisi pembangunan perikanan tangkap yang telah dilaksanakan di Indonesia, yang difokuskan pada pada dua aspek utama, yaitu komoditas utama perikanan tangkap tuna, tongkol dan cakalang (TTC) dan pelakunya serta bagaimana strategi keberlanjutannya. Selain itu, penelitian ini juga mencoba merumuskan indikator prioritas yang dapat digunakan untuk mengukur keberlanjutan pembangunan perikanan tangkap. Penelitian ini menggunakan metode analisis isi dan untuk mengetahui prioritas indikator digunakan pendekatan metode urgency, seriousness and growth (USG). Hasil kajian memberikan gambaran bahwa manfaat dari perikanan tangkap di Indonesia belum merata dirasakan. Struktur perikanan tangkap di Indonesia masih didominasi nelayan skala kecil dan berpengaruh terhadap produksi komoditas utama (TTC), Illegal, Unreported and Unregulated Fishing (IUUF) menjadi ancaman terbesar bagi keberlanjutan perikanan tangkap. Kondisi sumber daya ikan dan perikanan skala kecil menjadi indikator prioritas utama untuk mengukur keberhasilan perikanan tangkap yang berkelanjutan, sehingga kedepannya diperlukan perbaikan terhadap pengelolaan perikanan yang dapat ditempuh melalui pengelolaan sumberdaya ikan berbasis WPP melalui penguatan kelembagaan dan dukungan sarana prasarana.
\end{abstract}

Kata Kunci: keberlanjutan; komoditas utama; nelayan; perikanan tangkap, sumber daya

\section{ABSTRACT}

Capture fisheriy in Indonesia has a strategic role, though its implementation encounter such a complex problem. The threat on the sustainability of fish resources and fisher capacity are the major concern in creating sustainable capture fisheries. This study aims to examine the condition of capture fisheries development in Indonesia that focused on two main aspects: (1) the main commodities of tuna, little tuna and skipjack (TTC) and its fishers, and (2) the strategy for its sustainability. In addition, this study tries to formulate priority indicators to measure the sustainability of capture fisheries development. The research used content analysis method as well as Urgency, Seriousness and Growth (USG) method to determine priority indicators. Results of the study showed that the benefits of capture fisheries in Indonesia are not evenly distributed. Small-scale fishers dominate the structure of capture fisheries in Indonesia and affect the production of major commodities (TTC). In addition, Illegal, Unreported and Unregulated Fishing (IUUF) is the biggest threat to the sustainability of capture fisheries. The condition of fish resources and small-scale fishers is a top priority indicator to measure the success of sustainable capture fisheries, so it is necessary to improve future fisheries management based on WPP through institutional strengthening and infrastructure support.

Keywords: capture fisheries; fishers; main commodities; resources; sustainability 


\section{PENDAHULUAN}

Perikanan tangkap memiliki peran penting dan strategis di Indonesia, setidaknya dapat dilihat dari tiga peran, yaitu sumber pertumbuhan ekonomi, sumber pangan khususnya protein hewani, dan penyedia lapangan kerja (Purnomo ,2012; Triarso, 2012; Rizal, Iskandar, Herawati \& Dewanti 2018; Sanger, Jusuf \& Andaki 2019). Perikanan menciptakan lapangan kerja dan bertindak sebagai "jaring pengaman" ketika sumber penghasilan lainnya gagal (Bene \& Tewfik 2001; Bene, Macfadyen \& Allison 2007; Cunningham 1993; Machena \& Kwaramba 1997). Pentingnya perikanan tangkap tidak hanya terjadi di Indonesia namun juga di beberapa negara di Asia, Eropa dan Amerika. Fakta ini diungkapkan Fauzi (2010) bahwa sektor perikanan di beberapa negara di Eropa dan Amerika telah menjadi sumber "energi" dan mesin pertumbuhan ekonomi regional. Peran sektor perikanan di beberapa negara ditandai dengan tajamnya peningkatan produksi perikanan dunia. Bahkan untuk di China, perikanan tangkap berdampak secara ekonomi dan sosial (Huang \& $\mathrm{He}$ 2019). Fauzi \& Anna (2002) menyebutkan bahwa sumber daya perikanan sebagai salah satu aset penting negara apabila dikelola secara baik, dan memberikan manfaat maksimum bagi masyarakat. Sementara itu, kontribusi produksi perikanan tangkap laut di dunia terus menurun, hingga sebesar $46,38 \%$ dari total produksi perikanan dunia pada tahun 2016. Pada saat produksi perikanan meningkat, produksi perikanan tangkap di laut mengalami penurunan, dari sebesar 81,25 juta ton pada tahun 2015 menjadi 79,28 juta ton pada tahun 2016 (FAO, 2018).

Keberlanjutan pembangunan perikanan tangkap tidak hanya menghadapi permasalahan overfishing dan overcapacity, namun beberapa kajian mengatakan bahwa keberlanjutan perikanan tangkap juga menghadapi berbagai tekanan, baik disebabkan perubahan iklim, polusi, degradasi sumber daya maupun fluktuasi harga komoditas serta sengketa batas-batas nasional yang meningkatkan kerentanan bagi nelayan dan keberlanjutan perikanan tangkap (Garcia, Zerbi, Aliaume, Chi \& Lasserre 2003; Beddington, Agnew \& Clark 2007; Lieng, Yagi, Mori \& Hastings ,2018). Hal tersebut diperkuat oleh Bappenas (2014) yang menyatakan bahwa pembangunan perikanan tangkap berkelanjutan di Indonesia tidak terlepas dari beberapa isu utama antara lain terkait daya saing produk yang masih rendah, tidak berkembangnya pasar domestik, terbatasnya akses permodalan untuk pengembangan usaha, kualitas dan teknologi nelayan yang masih rendah, kegiatan illegal, Unregulated and Unreported (IUU) fishing, overfishing, lemahnya kapasitas kelembagaan pengawasan dan sistem pendataan perikanan tangkap yang masih lemah.

Perikanan tangkap di Indonesia memiliki peran yang besar terhadap produksi perikanan tangkap dunia. Hal tersebut tercantum pada laporan FAO (2018) yang menyatakan bahwa Indonesia telah berkontribusi terhadap produksi hasil tangkapan dunia sebesar $7,19 \%(6,54$ juta ton) pada tahun 2016 atau satu tingkat di bawah China sebesar 17,56 juta ton $(19,29 \%)$. Salah satu jenis sumber daya ikan yang memiliki potensi besar dari kelompok ikan pelagis besar adalah tuna, tongkol dan cakalang (TTC). TTC menjadi salah satu komoditas utama perikanan tangkap di Indonesia. Secara global, Indonesia memegang peranan penting TTC di dunia. Produksi TTC dunia sebesar 6,8 juta ton tahun 2011 dan meningkat menjadi 12,3 juta ton tahun 2017 dengan produksi rata-rata Indonesia sebesar 1,29 juta ton pada tahun 2012-2018 (KKP 2018). Kondisi industri perikanan tangkap di Indonesia secara umum masih di dominasi (lebih dari $80 \%$ ) nelayan skala kecil (dengan armada < $10 \mathrm{GT}$ ) dan menjadi mata pencaharian jutaan rumah tangga di wilayah pesisir. Perikanan skala kecil memberikan kontribusi yang signifikan terhadap ekonomi rumah tangga dan keamanan pangan (Kurien, 1993). Uraian diatas lebih banyak memberikan gambaran yang "indah" terhadap perikanan tangkap baik di Indonesia maupun di dunia. Namun, beberapa kajian telah menunjukkan bahwa perikanan tangkap di Indonesia mengalami kondisi penangkapan berlebih (overfishing) dan kapasitas penangkapan berlebih atau overcapacity (Sularso, 2004; Drajat, 2004; Waluyo, 2009; Mamuaya, Haluan, Wisudo, \& Astika, 2007; Fauzi, 2010; Wiyono, 2014; Widodo \& Widodo 2017). Tentu saja hal tersebut akan mengancam keberlanjutan perikanan tangkap itu sendiri.

Status pembangunan perikanan tangkap menjadi hal yang sangat penting untuk diketahui sebagai ukuran capaian pembangunan itu sendiri, efektivitas program yang telah dilakukan dan juga sebagai dasar perencanaan kedepannya. Perikanan tangkap di Indonesia dengan potensi yang besar dan kompleksitas permasalahan yang dihadapi tentu saja memiliki tantangan yang besar dalam mewujudkan pembangunan perikanan tangkap yang berkelanjutan. Sejauh ini, gambaran 
perikanan tangkap di Indonesia selalu disajikan dengan gambaran yang positif dengan berbagai target yang telah tercapai namun sisi lain (seperti permasalahan dan ancaman) dari pembangunan perikanan tangkap itu sendiri masih kurang banyak diungkapkan. Berdasarkan hal tersebut, penelitian ini akan mengkaji kondisi pembangunan perikanan tangkap yang telah dilaksanakan di Indonesia. Kajian terkait pembangunan perikanan tangkap ini akan difokuskan pada pada dua aspek utama, yaitu komoditas utama perikanan tangkap (TTC) dan pelakunya, khususnya yang mendominasi struktur perikanan tangkap nasional, yaitu nelayan skala kecil, sehingga diperoleh gambaran terkait pembangunan perikanan tangkap dari sisi sumber daya (komoditas utama/TTC) dan juga pelaku usahanya (nelayan skala kecil) dan bagaimana strategi keberlanjutannya. Selain itu, penelitian ini juga mencoba merumuskan indikator-indikator yang dapat digunakan untuk mengukur kerberlanjutan pembangunan perikanan tangkap sebagai langkah awal untuk mewujudkan pembangunan perikanan tangkap berkelanjutan. Hasil dari penelitian ini diharapkan dapat menjadi bahan untuk memformulasikan kebijakan keberlanjutan perikanan tangkap di Indonesia.

\section{Jenis dan Sumber Data}

Berdasarkan jenisnya, data yang digunakan dalam penelitian ini terdiri dari data sekunder dan primer. Data sekunder yang dikumpulkan berupa laporan hasil penelitian terdahulu, statistik perikanan tangkap, data PDB, potensi sumber daya perikanan dan jenis data lainnya terkait penelitian. Data sekunder diperoleh dari Badan Pusat Statistik, Kementerian Kelautan dan Perikanan, perguruan tinggi, lembaga penelitian dan institusi terkait lainnya. Data primer yang dikumpukan berupa karakteristik responden dan persepsi terhadap prioritas indikator yang dapat mengukur kinerja pembangunan perikanan tangkap.

\section{Teknik Pengumpulan Data}

Pengumpulan data sekunder dilakukan melalui studi literatur ke berbagai sumber, baik instansi pemerintah maupun perguruan tinggi. Untuk memperdalam informasi dari hasil kajian desk study kemudian juga dilakukan wawancara mendalam dengan beberapa informan kunci, seperti pelaku usaha (nelayan), pengelola pelabuhan perikanan dan informan lainnya terkait tujuan penelitian. Sementara pengumpulan data primer dilakukan dengan menggunakan angket dan wawancara mendalam seperti yang telah disampaikan sebelumnya. Jumlah responden pada penelitian ini adalah sebanyak 20 orang yang difokuskan kepada peneliti, perencana dan pengambil kebijakan.

\section{Teknik Analisis Data}

Analisis data dilakukan dengan metode analisis isi (content analysis), yaitu alat untuk mengikuti rekam jejak dari pelaksanaan, mulai dari landasan teori yang digunakan sampai dengan praktik yang dilakukan serta mengilustrasikan dari beragam data set yang telah disusun (Hsieh \& Shannon, 2005; Hopkins \& King, 2010; Elo et al., 2014). Pada pelaksanaannya dilakukan terlebih dahulu observasi berbagai artikel, buku dan terbitan ilmiah lainnya sehingga dapat disusun analisis secara deskriptif. Analisis data secara deskriptif digunakan untuk menginterpretasikan data mentah berupa data primer dan sekunder menjadi suatu bentuk yang mudah dimengerti dan diterjemahkan (Martono, 2010), sehingga dapat menggambarkan fenomena dan kausalitas dari objek yang dikaji (Loeb, Dynarski, McFarland, Morris \& Reardon 2017). Selanjutnya, untuk merumuskan indikatorindikator yang dapat digunakan untuk mengukur keberlanjutan pembangunan perikanan tangkap dilakukan dengan cara berjenjang yang diawali melalui desk study dari hasil penelitian yang telah ada. Indikator yang disusun mewakili beberapa dimensi (ekonomi, ekologi, sosial dan kelembagaan). Selanjutnya, untuk mengetahui prioritas indikator digunakan pendekatan metode urgency, seriousness and growth (USG). Metode USG dapat menetapkan urutan prioritas masalah dengan teknik scoring (skala likert) dan dilakukan dengan memperhatikan urgensi dari masalah, keseriusan masalah yang dihadapi, dan kemungkinan bekembangnya masalah (Kepner \& Tregoe 1981; Husnayain 2015).

\section{HASIL DAN PEMBAHASAN}

\section{Potret Komoditas Utama Perikanan Tangkap : Tuna, Tongkol dan Cakalang}

Tuna, tongkol dan cakalang (TTC) merupakan komoditas utama perikanan tangkap Indonesia yang termasuk kedalam kelompok pelagis besar, memiliki karakteristik oseanik atau sifat selalu beruaya dari suatu perairan ke perairan lain dengan kondisi oseanografi dan biologis sesuai habitatnya (Sibagariang, Fauziyah \& Agustriani, 2011). Daerah penangkapan TTC tersebar, dari kawasan barat sampai timur Indonesia. Sedikit berbeda dengan 


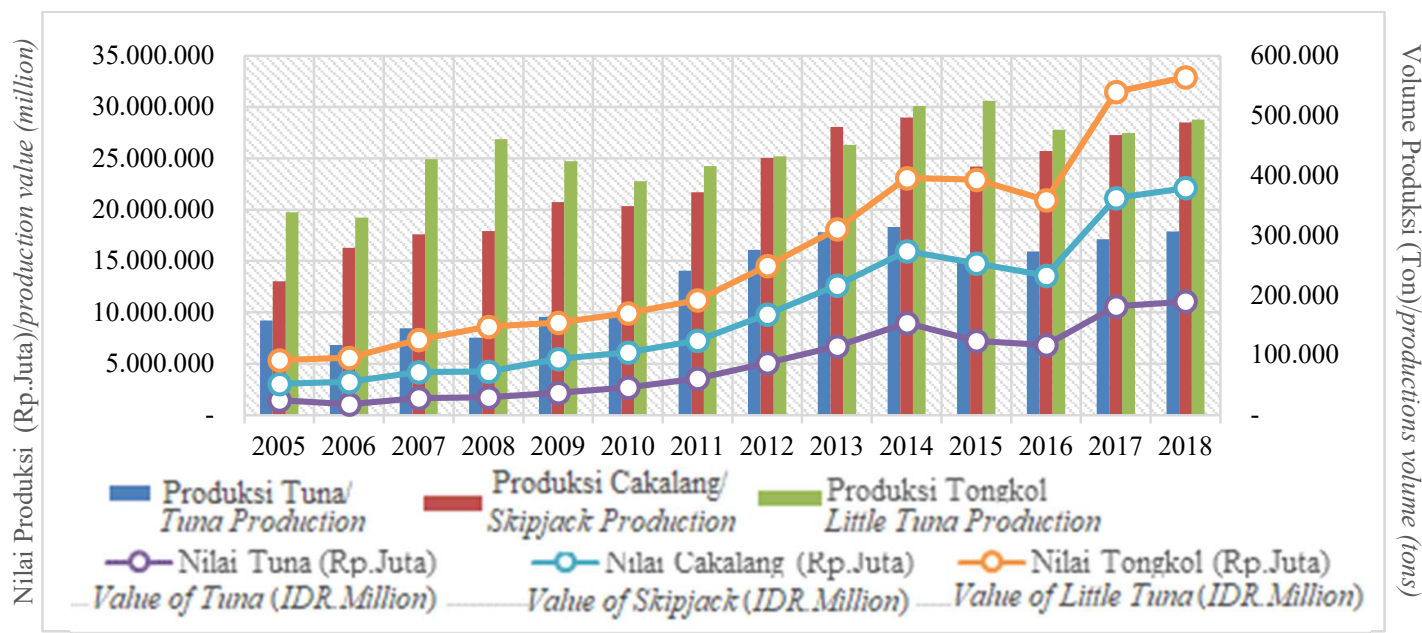

\section{Gambar 1. Volume (ton) dan Nilai Produksi Tuna, Cakalang dan Tongkol. Figure 1. The volume (ton) and Value of Tuna, Skipjack Tuna and Little Tuna Production.}

Sumber : Statistik Perikanan Tangkap Indonesia (2005-2016) dan Pusdatin (2017-2018)/ Source: Indonesian Capture Fisheries Statistics (2005-2016) and Pusdatin (2017-2018)

penangkapan ikan umumnya, penangkapan TTC membutuhkan alat tangkap yang lebih spesifik sangat bergantung pada armada yang digunakan. Umumnya armada modern menggunakan alat tangkap berupa longline, sedangkan tradisional berupa pancing ulur, pancing layang-layang, atau pun pancing hanyut. Penyebaran TTC di Indonesia meliputi Samudera Indonesia, pantai barat Sumatera, Selatan Jawa, Bali, Nusa Tenggara, perairan Indonesia Timur meliputi Laut Banda, Laut Flores, Laut Maluku, Laut Makassar (Uktolseja 1987). Penentuan lokasi penangkapan cakalang ditentukan musim berbeda di setiap perairan, tetapi dapat dilakukan sepanjang tahun.

TTC memiliki nilai ekonomis penting dan banyak tersebar hampir di seluruh wilayah perairan Indonesia. Nilai ekonomis menjadikan TTC sebagai komoditas utama perikanan tangkap dan Indonesia memasok lebih dari $16 \%$ produksi TTC dunia (FAO, 2018). Volume ekspor TTC mencapai sekitar 168.434 ton (USD 713,9 juta) pada tahun 2018 (KKP, 2019). Produksi TTC pada periode tahun 2005-2018 mengalami peningkatan rata-rata 1,049 juta ton dan nilai produksi sebesar 31,47 triliun rupiah. TTC memberikan kontribusi signifikan terhadap produksi perikanan nasional yaitu sekitar $20 \%$ dari total produksi perikanan tangkap (Firdaus et al., 2018).

Secara agregat produksi cakalang dan tongkol lebih tinggi dibandingkan tuna (Gambar 1), meskipun demikian produksi ketiga komoditas tersebut mengalami fluktuatif sejak tahun 2005 sampai dengan 2018. Produksi ikan tongkol tertinggi yaitu pada tahun 2015 sebesar 524.387 ton, sedangkan untuk produksi ikan cakalang dan tuna tertinggi pada tahun 2014 dengan masingmasing produksi sebesar 496.682 ton dan 313.873 ton. Sedangkan dari sisi nilai, meskipun produksi tuna lebih kecil tetapi memiliki nilai yang lebih tinggi (Firdaus, 2018a). Hasil kajian Firdaus (2018b), harga rata-rata tuna per $\mathrm{kg}$ mencapai lebih dari Rp. $35.000,-/ \mathrm{kg}$ sedangkan untuk tongkol dan cakalang harganya kurang dari Rp. 20.000,-/kg. TTC memiliki kontribusi positif terhadap ekonomi nasional, tetapi tidak terlepas dari masalah yang kompleks. Menurut Fauzi (2010), tekanan terhadap sumber daya yang cukup masif dapat menyebabkan terjadinya penurunan kualitas dan kuantitas sumber daya ikan. Hal ini terlihat juga pada TTC, dimana ukuran ikan yang tertangkap semakin kecil dan ruang ekspansi semakin sulit dilakukan. Lebih lanjut Fauzi (2010) menyebut bahwa tekanan yang masif terhadap sumber daya ikan disebabkan dua hal utama, yakni over fishing (baik secara ekonomi maupun biologi) dan terjadinya ekses kapasitas (over capacity) pada perikanan ekonomis penting, sehingga berimplikasi serius terhadap aspek sosial dan ekonomi (Beddington et al., 2007).

Meskipun trend produksi TTC sejak tahun 2014 sampai dengan 2018 cenderung menurun, namun secara umum trend peningkatan produksi perikanan tangkap nasional tahun 2018 lebih tinggi dibandingkan perikanan budidaya yaitu $7,47 \%$ dengan kontribusi perikanan tangkap nasional sebesar $49,64 \%$ terhadap perolehan total PDB perikanan. Meskipun capaian perikanan tangkap 
memberikan gambaran pertumbuhan produksi dan manfaat ekonomi yang positif, namun disisi lain pada kenyataanya dari hasil kajian Rizal et al. (2018) menunjukkan bahwa hampir $70 \%$ nelayan di Indonesia masih terjebak dalam kemiskinan. Hal ini menunjukkan bahwa secara nyata perikanan tangkap di Indonesia belum memberikan manfaat yang merata.

Perikanan TTC tidak terlepas dari permasalahan IUUF yang telah menjadi isu internasional. Karakteristik TTC yang high migratory sangat rentan terhadap praktek IUUF yang menimbulkan kerugian secara ekonomi, disamping menimbulkan masalah lingkungan dan dampak sosial (Sowman \& Bergh 2006; Miller \& Sumaila 2016; Nova 2017). IUUF diduga menjadi salah satu penyebab pelaporan secara statistik jumlah produksi TTC tidak signifikan dengan kenaikan jumlah alat tangkap yang digunakan. Produksi yang tidak terlaporkan dari komoditas TTC telah memberikan dampak secara statistik nilai produksi tidak akurat. Hasil penelitian Wijaya et al. (2012) menunjukkan adanya indikasi perdagangan tuna dan cakalang di tengah laut perairan Indonesia untuk dijual secara langsung ke negara Filipina sehingga produksi tangkapannya tidak tercatat pada pelabuhan base kapal penangkapan di Indonesia. Hal ini sejalan dengan hasil penelitian Syahrani, Musadieq \& Darmawan (2017) yang mengungkapkan bahwa komoditas tuna rentan adanya praktek IUUF, khususnya unreported terhadap hasil tangkapan.

\section{Potret Perikanan Skala Kecil di Indonesia}

Perikanan skala kecil erat kaitannya dengan definisi nelayan skala kecil atau small scale fisheries. Berdasarkan UU No. 45 Tahun 2009 tentang perubahan atas UU No. 31 Tahun 2004, nelayan skala kecil diartikan sebagai orang yang mata pencahariannya melakukan penangkapan ikan guna memenuhi kebutuhan hidup sehari-hari menggunakan kapal perikanan berukuran paling besar 5 GT. Pada tahun 2016, definisi hukum nelayan kecil kembali mengemuka melalui UU No.7/2016, dimana nelayan kecil didefinisikan sebagai nelayan yang melakukan penangkapan ikan untuk memenuhi kebutuhan hidup sehari-hari, baik yang tidak menggunakan kapal penangkap ikan maupun yang menggunakan kapal penangkap ikan berukuran paling besar 10 GT. Sementara dalam PP No.32 tahun 2019, nelayan kecil diartikan sebagai nelayan yang melakukan penangkapan ikan untuk kebutuhan hidup sehari-hari, baik yang tidak menggunakan kapal penangkap ikan maupun yang menggunakan kapal penangkap ikan berukuran paling besar $10 \mathrm{GT}$.

Berdasarkan data statistik tahun 2016, jumlah armada penangkapan ikan berukuran kurang dari 10 GT atau yang masuk kedalam kategori nelayan skala kecil adalah sebanyak 508.551 unit atau 94\% dari total armada yang ada. Kondisi ini menunjukkan usaha perikanan tangkap masih didominasi nelayan skala kecil dengan teknologi yang sederhana. Struktur nelayan di Indonesia yang masih didominasi nelayan skala kecil yang umumnya erat dengan kemiskinan. Widodo (2009) menjelaskan nelayan kecil hanya mampu memanfaatkan sumber daya di daerah pesisir dengan hasil tangkapan yang cenderung terus menurun akibat persaingan dengan kapal besar dan penurunan mutu sumber daya pantai. Hasil tangkapan juga mudah rusak sehingga melemahkan posisi tawar mereka dalam transaksi penjualan. Pola hubungan eksploitatif antara pemilik modal dengan buruh dan nelayan, serta usaha nelayan yang bersifat musiman dan tidak menentu menyebabkan masyarakat miskin di kawasan pesisir cenderung sulit untuk keluar dari jerat kemiskinan dan belitan utang pedagang atau pemilik kapal.

Otoritas perikanan di negara-negara berkembang mungkin terbatas kapasitasnya dalam mengelola perikanan tangkap skala kecil. Ketidakmampuan ini disebabkan karena penggunaan metode-metode pengelolaan perikanan konvensional yang dikembangkan di negara maju yang tidak cocok untuk perikanan tangkap skala kecil. Menghadapi kenyataan tersebut, diperlukan berbagai kebijakan untuk mengembangkan usaha nelayan skala kecil. Nizar (2015) menjelaskan bahwa pengembangan usaha dapat dilakukan dengan melihat beberapa aspek, yaitu teknis, ekonomi, sosial, finansial, dan manajemen sehingga pengembangan usaha perikanan tangkap skala kecil dapat terwujud secara berkelanjutan. Hasil penelitian Gokturk dan Deniz (2017) menunjukkan bahwa dalam pengembangan perikanan skala kecil berkelanjutan dapat dilakukan dengan pembenahan pengelolaan perikanan. Hal serupa juga dialami oleh Indonesia saat yang mengarahkan pengelolaan perikanan kedepan berbasis wilayah pengelolaan perikanan (WPP). 
Tabel 1. Tingkat Pemanfaatan Ikan Pelagis Besar (Non Tuna-Cakalang) di 11 WPP Tahun 2011-2019. Table 1. Level of Utilization of Big Pelagic Fish (Non Tuna-Skipjack Tuna) in 11 WPP 2011-2019.

\begin{tabular}{ccccccc|c|c|c|c|c} 
Tahun/Year & \multicolumn{9}{c}{ Wilayah Pengelolaan Perikanan (WPP)/Fisheries Management Area (FMA) } \\
& $\mathbf{5 7 1}$ & $\mathbf{5 7 2}$ & $\mathbf{5 7 3}$ & $\mathbf{7 1 1}$ & $\mathbf{7 1 2}$ & $\mathbf{7 1 3}$ & $\mathbf{7 1 4}$ & $\mathbf{7 1 5}$ & $\mathbf{7 1 6}$ & $\mathbf{7 1 7}$ & $\mathbf{7 1 8}$ \\
$\mathbf{2 0 1 1}$ & 0,81 & 1,01 & 1,24 & 0,65 & 0,87 & 1,05 & 0,71 & 0,85 & 0,60 & 0,39 & 1,15 \\
2016 & 0,89 & 1,29 & 0,73 & 0,42 & 1,16 & 0,86 & 0,86 & 1,58 & 0,74 & 0,95 & 0,65 \\
2017 & 0,52 & 0,95 & 1,06 & 0,93 & 0,63 & 1,13 & 0,78 & 0,97 & 0,63 & 1,00 & 0,99 \\
$\left.2019^{*}\right)$ & 0,52 & 0,95 & 1,06 & 0,32 & 0,75 & 1,13 & 0,78 & 0,47 & 0,50 & 1,00 & 0,30 \\
\hline
\end{tabular}

Keterangan Tingkat pemanfaatan $(\mathrm{E}): /$ Remaks on the level of utilization $(\mathrm{E})$ :

$E<0.5=$ Moderate; $0.5 \leq E<1=$ Fully-exploited; $E \geq 1=$ Over-exploited

*) Hasil pertemuan Komnas Kajiskan Juni 2019/the results of Komnas Kajiskan meeting, June 2019

Secara umum, pelaku usaha penangkapan ikan TTC di Indonesia masih didominasi kapal kecil dengan alat tangkap yang sederhana, seperti pancing (handline), sedangkan armada kapal besar diatas $60 \mathrm{GT}$ masih sangat sedikit pasca moratorium kapal eks asing (https: //www. mongabay.co.id /2019/01/21/ mengapa-penangkapan-tuna-masihdidominasi-nelayan-skala-kecil/ diunduh pada 7 Juli 2019). Hal ini berkorelasi dengan hasil tangkapan TTC yang lebih banyak dihasilkan nelayan skala kecil sehingga menjadi tantangan terhadap keberlanjutan TTC skala kecil di Indonesia, disamping adanya kompetisi antara pelaku usaha skala kecil dengan skala industri. Septisafitri (2010) dalam penelitiannya menyebut upaya pengembangan perikanan tangkap berbasis komoditas ikan unggulan dapat dilakukan dengan berbagai cara, antara lain: memperluas jangkauan daerah penangkapan ikan diatas 12 mil. Hal ini menjadi tantangan bagi para nelayan skala kecil untuk meningkatkan kapasitas usahanya melalui peningkatan ukuran armada dan teknologi alat tangkapnya.

\section{Keberlanjutan Perikanan Tangkap di Indonesia}

\section{a. Tinjauan Aspek Ekologi}

Indonesia saat ini terus mendorong perikanan skala kecil untuk menerapkan prinsip penangkapan ikan berkelanjutan dan bertanggung jawab. Dorongan berkelanjutan terus difokuskan pada nelayan skala kecil yang terlibat dalam praktik penangkapan dan tata kelola perdagangan tuna. Berdasarkan aspek ekologi, keberlanjutan perikanan secara ekologi dapat dilihat dari kondisi stok sumber daya perikanan tangkap itu sendiri.

Status pemanfaatan ikan pelagis besar di Indonesia berdasarkan WPP diketahui mengalami penurunan sejak tahun 2011 hingga 2019, dimana status pemanfaatan terus meningkat menuju arah yang lebih mengkhawatirkan di beberapa WPP, antara lain WPP 572, 573 dan 713. Pada Tabel 1, terlihat adanya perubahan warna tingkat pemanfaatan menjadi warna kuning dan merah yang menandakan adanya deplesi atau pengurangan kualitas sumber daya ikan tersebut. Menurut Fauzi \& Anna (2002) deplesi dapat diartikan sebagai laju pengurangan stok sumber daya ikan. Deplesi memberikan dampak negatif terhadap sumber daya dan ekonomi (Firdaus 2018a).

Tingkat pemanfaatan ikan pelagis besar tidak terlepas dari peningkatan produksi yang terus meningkat sejak tahun 2005 hingga 2018. Laju pertumbuhan produksi perikanan tangkap untuk komoditas TTC selama tahun 2011 hingga 2018 mencapai $18,2 \%$ per tahun (KKP 2019). Peningkatan laju produksi yang cukup tinggi memberikan tekanan terhadap sumber daya, tercermin dari status tingkat pemanfaatannya. Penurunan kualitas sumber daya atau deplesi sumber daya tentu saja diperlukan sebuah solusi untuk tetap menjaga keberlanjutannya. Salah satu yang dapat dilakukan adalah dibentuknya kawasan konservasi. Kawasan konservasi dapat berfungsi sebagai daerah perlindungan, tempat spawning ground dan nursery ground bagi beberapa ikan jenis pelagis. Ikan pelagis besar yang bersifat high migratory tentu saja akan beruaya lintas WPP. Beberapa WPP yang sudah berada pada tingkat pemanfaatan over exploited menjadi prioritas peningkatan luas kawasan konservasinya.

Kawasan konservasi pesisir dan pulau-pulau kecil terluas berada di WPP 711, mencapai 2,76 juta hektar sehingga memiliki korelasi positif terhadap status tingkat pemanfaatannya (Lampiran 1). Begitupun pada WPP 713 yang memiliki kawasan konservasi yang lebih sempit, maka memiliki tingkat pemanfaatan ikan pelagis besar yang jauh lebih tinggi (over exsploited). Tentu saja hal ini bukan 
menjadi salah satu faktor dan ada banyak faktor lainnya termasuk jumlah armada, nelayan dan alat tangkap yang ada di WPP tersebut.

Menurut Fauzi (2005), salah satu faktor penghambat pembangunan perikanan tangkap berkelanjutan adalah kegiatan IUUF. Bappenas (2014) menyebut kegiatan IUUF menjadi bagian isu lingkungan dalam pelaksanaan pembangunan perikanan berkelanjutan yang memberikan dampak degradasi dan overfishing sumber daya ikan, disamping hilangnya nilai devisa serta pendapatan ekonomi lainnya. Meningkatnya aktivitas IUUF membuat FAO (2001) menerbitkan the international plan of action on IUUF yang mengamanahkan setiap negara anggota menyusun national plan of action (NPOA) untuk mencegah, menghalangi dan menghilangkan IUUF yang bertentangan dengan CCRF dan sangat mengganggu upaya pengelolaan perikanan dan merugikan negara dalam melaksanakan pembangunan perikanan yang bertanggungjawab. Maraknya IUUF telah menimbulkan masalah lingkungan, sosial dan ekonomi (Fauzi, 2010). Kerugian IUUF beragam dan diestimasi sebesar $30 \%$ dari total tangkapan ikan ekonomis penting (FAO 2009). Kerugian IUUF diestimasi berkisar antara US\$2 sampai US $\$ 10$ miliar (Fauzi, 2010). IUUF juga memicu dampak adanya konflik antara nelayan yang berbeda alat tangkap maupun nelayan dengan alat tangkap yang sama sehingga menimbulkan konflik sosial diantara masyarakat pesisir (Adhuri, Wahyono \& Indrawasih, 2005; Solihin, 2010).

Berdasarkan Gambar 2, terlihat selama tahun 2007-2018 sebanyak 1.651 kapal IUUF dari 9 negara ditangkap kapal pengawas KKP di perairan Indonesia. Kapal asal Vietnam memimpin pelaku penggaran IUUF dengan 635 kapal $(38,46 \%)$, diikuti Indonesia $(37,55 \%)$, Malaysia $(8,18 \%)$ dan Thailand $(7,09 \%)$. Pelanggaran yang umum dilakukan kapal tersebut adalah melakukan kegiatan penangkapan tanpa disertai dokumen perizinan yang sah, penggunaan alat tangkap yang dilarang, dan ketidaksesuaian lokasi daerah penangkapan. Selama periode tersebut, jumlah pelaku IUUF terendah terjadi pada tahun 2014 dan tertinggi pada tahun 2008. Sedangkan pada periode tahun 2016-2018, jumlah pelaku IUUF terus terjadi penurunan dan berbanding lurus dengan peningkatan hasil tangkapan laut secara nasional pada periode yang sama. Adanya peningkatan stok sumber daya ikan beberapa tahun terakhir berdasarkan hasil kajian menunjukkan dengan tujuan pembangunan perikanan secara ekologis berkelanjutan, manakala basis ketersediaan stok atau sumber daya ikan dapat dipelihara secara stabil, tidak terjadi eksploitasi berlebihan (Gallic ,2002).

\section{b. Tinjauan Aspek Ekonomi}

Sektor perikanan tangkap di Indonesia memiliki peran yang penting bagi perekonomian, terlihat dari banyaknya pelaku utama di sektor ini. Berdasarkan data statistik diketahui laju pertumbuhan RTP perikanan tangkap tahun 2000 hingga 2016 sebesar 2,6\% per tahun. Jumlah RTP tangkap tahun 2000 sebanyak 475.392 RTP dan meningkat menjadi 683.249 RTP pada tahun 2016. Jika dalam satu RTP berjumlah 4 (empat) orang anggota rumah tangga, maka diperkirakan

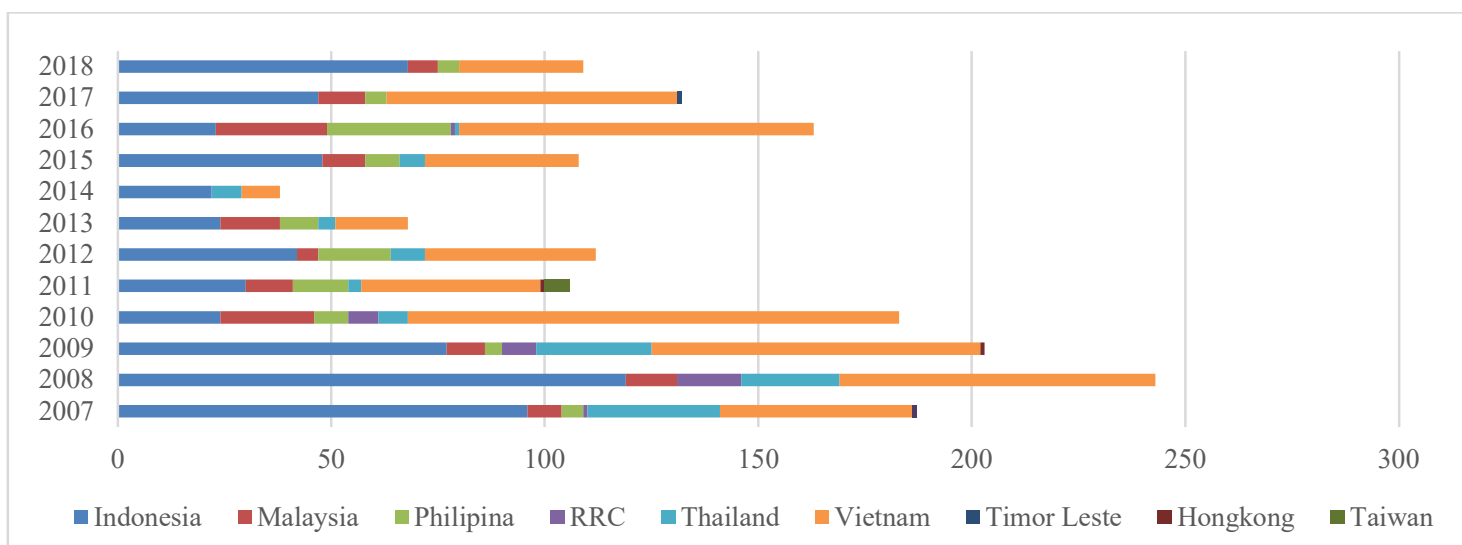

Gambar 2. Rekapitulasi Kapal Hasil Tangkapan Kapal Pengawas Berdasarkan Negara Tahun 2007-2018 Figure 2. Recapitulation of the Catch of the Surveillance Ship by Country in 2007-2018. 
lebih dari 2,7 juta orang bergantung terhadap perikanan tangkap. Keberlanjutan perikanan tangkap secara ekonomi (keberlanjutan ekonomi) ditinjau berdasarkan aspek ekonomi secara makro dari komoditas utama perikanan tangkap TTC. Secara total komoditas TTC memberikan kontribusi $20 \%$ terhadap total produksi perikanan tangkap. Perkembangan volume ekspor TTC selama 10 tahun terakhir (2008-2018) berfluktuasi. Volume ekspor lebih rendah belum tentu memberikan besaran nilai ekspor yang rendah (Gambar 3). Besaran nilai ekspor perikanan TTC di Indonesia terus mengalami peningkatan sejak tahun 2008, puncaknya terjadi pada tahun 2013, dan mengalami penurunan hingga tahun 2016, tetapi dua tahun terakhir kembali beranjak naik. Tingginya permintaan dunia terhadap TTC mendorong perkembangan usaha penangkapan TTC di dalam negeri, dicirikan semakin meningkatnya jumlah alat tangkap yang digunakan untuk menangkap ikan tersebut.

Jumlah alat tangkap (rawai tuna, huhate dan pancing tonda) tahun 2000 adalah sebanyak 64.611 unit dan meningkat menjadi 108.025 unit pada tahun 2009, kemudian turun menjadi 85.239 unit pada tahun 2015 (Firdaus, 2018b). Penurunan jumlah alat tangkap pada tahun 2015 tidak terlepas dari adanya kebijakan moratorium kapal yang dikeluarkan Pemerintah pada akhir tahun 2014. Dominasi nelayan skala kecil pada perikanan TTC di Indonesia tentu saja memiliki pengaruh besar karena nelayan kecil identik dengan teknologi sederhana sehingga mempengaruhi kualitas hasil tangkapan. Hasil wawancara dengan beberapa pengelola pelabuhan perikanan samudera Bungus, pelabuhan perikanan samudera Bitung, dan pelabuhan perikanan nusantara Sibolga disampaikan bahwa jumlah ikan tuna yang memiliki kualitas ekspor (grade A) pada nelayan skala kecil rata-rata hanya $20 \%$ dari total hasil tangkapan. Kualitas ikan ekspor umumnya memiliki beberapa kriteria, seperti kesegaran dan kualitas kekenyalan dagingnya, yang sangat dipengaruhi penanganan ikan di atas kapal dan sistem pendingin kapal. Jika sistem penanganan rantai dingin nelayan skala kecil dapat ditingkatkan tentu akan mempengaruhi volume ikan yang diekspor.

Nilai pendapatan rumah tangga perikanan (RTP) nelayan selama tahun 2008-2018 diketahui sebesar Rp.7,42 juta per bulan (Gambar 4). Pendapatan rumah tangga ini diestimasi dari seluruh atau merupakan akumulasi dari pendapatan seluruh anggota keluarga nelayan yang bekerja di sektor penangkapan, sedangkan nilai rata-rata pendapatan nelayan selama periode 2008-2018 adalah sebesar Rp.2,1 juta per bulan. Nilai ini jauh lebih tinggi jika dibandingkan dengan nilai rata-rata upah minimum regional secara nasional sebesar Rp.1,4 juta per bulan. Hal ini sejalan dengan pendapat Gallic (2002), bahwa tujuan pembangunan perikanan secara ekonomis dianggap berkelanjutan apabila sektor ini mampu menghasilkan produk ikan secara berkesinambungan (on continuing basis), memberikan kesejahteraan finansial pelakunya, dan memberikan sumbangan devisa serta pajak yang signifikan bagi negara

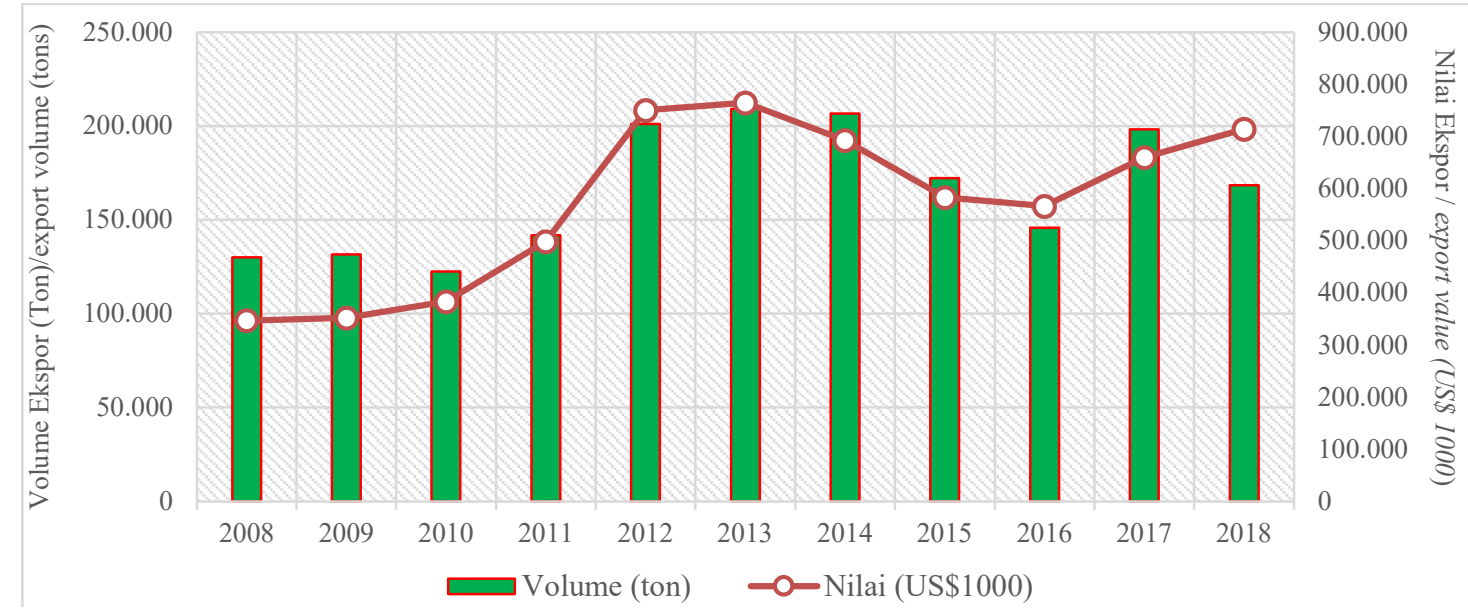

Gambar 3. Volume (ton) dan Nilai Ekspor (US\$ 1000) TTC Tahun 2008-2018

Figure 3. Volume (tons) and Export Value (US 1000) of Tuna, Skipjack Tuna and Little Tuna in 2008-2018. Sumber/Source: KKP 2019 


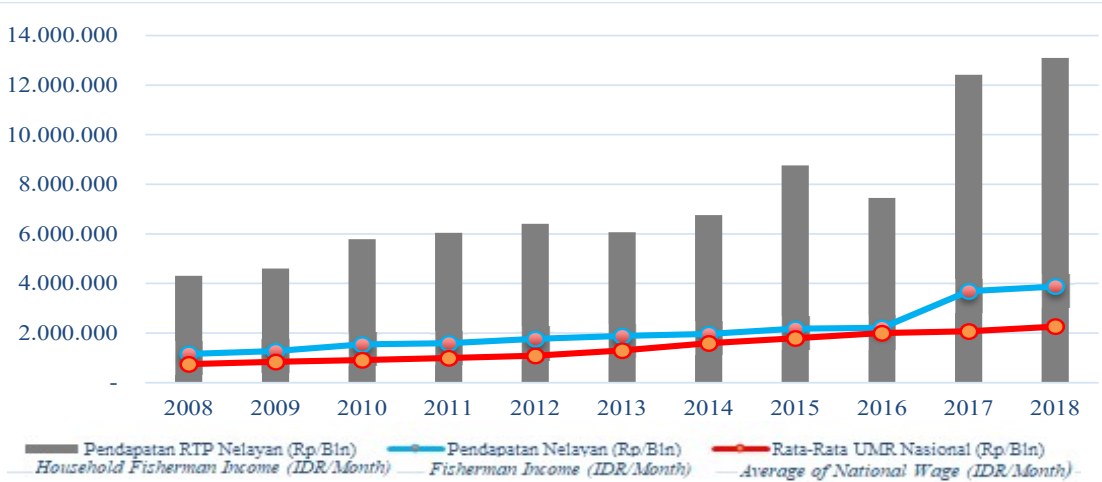

Gambar 4. Nilai Pendapatan RTP, Nilai Pendapatan Nelayan dan Nilai UMR Tahun 2008 - 2018 (Rp/Bulan) Figure 4. Value of RTP Income, Value of Fishers Revenue and UMR Value for 2008 - 2018 (IDR/Month) Sumber/Source: KKP 2019

Secara umum pendapatan nelayan dari hasil penangkapan ikan dapat memenuhi kebutuhan pokok hidupnya. Jika dibandingkan, pendapatan nelayan lebih tinggi dibandingkan UMR rata-rata nasional sehingga menjadi salah satu indikator pencaharian dari kegiatan perikanan tangkap memiliki peluang keberlanjutan. Berdasarkan Surat Edaran Menteri Tenaga Kerja RI No. SE-07/ MEN/1990, disebutkan bahwa komponen UMR telah memperhitungkan biaya hidup yang wajar sehingga dapat disimpulkan pendapatan nelayan sudah mampu memenuhi kebutuhan hidup. Meskipun demikian, pendapatan atau penghasilan usaha nelayan memiliki ketidakpastian yang tinggi atau tidak tetap, khususnya saat terjadi musim paceklik sehingga diperlukannya pelatihan atau pembekalan keterampilan usaha di bidang lainnya, seperti pengolahan ikan maupun lainnya sesuai kondisi sumber daya.

Pendapatan nelayan tidak terlepas dari investasi usaha, modal usaha dan penerimaan setelah operasi penangkapan. Adanya modal usaha dalam operasi penangkapan dapat memberikan kemudahan dalam usaha penangkapan ikan, serta sebagai sarana nelayan untuk mencari ikan di laut. Besarnya modal usaha yang digunakan dalam kegiatan operasi penangkapan ikan dapat menentukan keberhasilan hasil tangkapan nelayan (Jamal, Sondita, Wiryawan \& Haluan, 2014).

\section{c. Tinjauan Aspek Sosial}

Keberlanjutan sosial perikanan tangkap dapat dilihat dari banyaknya pelaku dan jumlah kejadian konflik antar pelaku atau pemanfaat sumber daya perikanan. Konflik antar nelayan lokal dengan nelayan asing di Indonesia sudah jauh berkurang sebagai akibat diberlakukannya moratorium kapal eks asing dan peningkatan pengawasan sumber daya perikanan, khususnya di wilayah perbatasan RI. Penggunaan alat tangkap destruktif, seperti cantrang sudah dilarang dan hal ini berdampak positif terhadap keberlanjutan perikanan tangkap. Partisipasi pemangku kepentingan dan peran masyarakat lokal terhadap pengelolaan sumber daya ikan menjadi salah satu faktor utama dalam menjaga keberlanjutan perikanan tangkap.

Kondisi sumber daya perikanan yang open acces menyebabkan setiap orang berlomba mengekstraksi sumber daya ikan sebanyakbanyaknya sehingga menyebabkan kelangkaan sumber daya. Pada sisi lain unit penangkapan ikan cenderung bertambah sehingga produktifitas nelayan semakin berkurang. Pihak yang terlibat konflik umumnya nelayan tradisional dalam memperebutkan daerah penangkapan ikan yang sama. Konflik nelayan merupakan fenomena yang telah terjadi sejak dulu, bahkan sebelum adanya era otonomi daerah. Keleluasaan mengeksploitasi sumber daya perikanan merupakan konsekuensi ciri kepemilikan bersifat terbuka (open acces). Menurut Soekanto (2002) penyebab utama terjadinya konflik nelayan adalah perbedaan kepentingan individu, perbedaan budaya, perbedaan kepentingan dan perubahan sosial. Menurut Adhuri et al. (2005) konflik kenelayanan ini harus segera diatasi, mengingat konflik besar terjadi akibat akumulasi konflik yang relatif lebih kecil atau sederhana tetapi diabaikan dalam jangka waktu yang lama sehingga diperlukan pengelolaan konflik guna membatasi dan mengatasi kekerasan perilaku yang terjadi. Jika konflik sosial nelayan dapat diminimalisir (bahkan tidak terjadi), maka tujuan pembangunan perikanan berkelanjutan secara sosial dapat dianggap tercapai (Gallic 2002). 


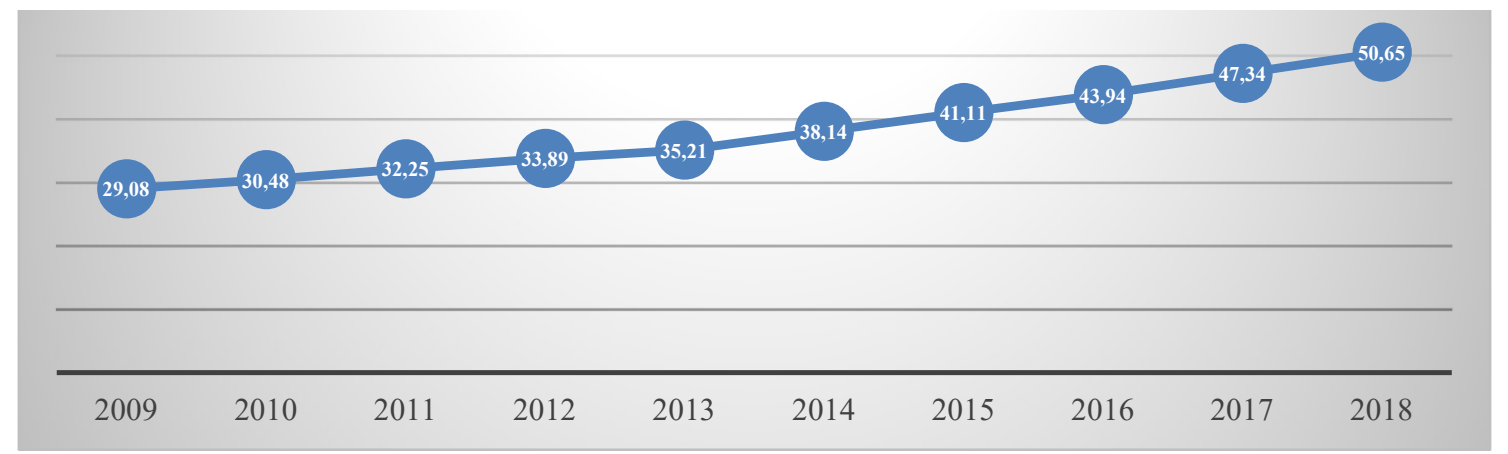

Gambar 5. Perkembangan Tingkat Konsumsi Ikan Nasional Tahun 2009-2018.

Figure 5. Development of National Fish Consumption Levels in 2009-2018.

Sumber/Source: KKP 2019

Salah satu peran perikanan dalam pembangunan adalah sebagai sumber pangan, khususnya protein hewani. Dalam hal penyediaan ikan sebagai sumber protein hewani terus meningkat setiap tahunnya, dari konsumsi ikan sebesar 29,08 kg/kapita/tahun pada tahun 2009 menjadi 50,65 kg/kapita/tahun pada tahun 2018 atau kenaikan rata-rata sebesar 6,37\% per tahun (Gambar 5). Komoditas yang berperan besar dalam peningkatan konsumsi ikan nasional adalah TTC, rata-rata berkontribusi sebesar $17,08 \%$ atau $8,66 \mathrm{~kg} / \mathrm{kapita} / \mathrm{tah}$ un selama periode tahun 2015-2018.

Sebagai sumber bahan pangan, peningkatan konsumsi ikan nasional berperan ganda, sebagai penghela industri perikanan nasional, juga dapat mengurangi beban penyakit untuk mewujudkan kualitas hidup masyarakat yang lebih baik dalam meningkatkan produktivitasnya. Apabila dibandingkan beberapa negara tetangga, seperti Malaysia (70 kg/kapita/tahun), Singapura (80 kg/ kapita/tahun), dan Jepang (100 kg/kapita/tahun), tingkat konsumsi ikan nasional masih jauh tertinggal.

\section{d. Tinjauan Aspek Kelembagaan}

Aspek kelembagaan merupakan salah satu aspek yang perlu diperhatikan dalam menjaga keberlanjutan sumber daya ikan. Tujuh indikator utama dalam menilai keberlanjutan perikanan tangkap secara kelembagaan, yaitu: keberadaan otoritas tunggal pengelolaan perikanan, tingkat sinergisitas kebijakan dan kelembagaan pengelolaan perikanan, peningkatan kapasitas pemangku kepentingan, mekanisme kelembagaan, kelengkapan aturan main dalam pengelolaan perikanan, rencana pengelolaan perikanan, dan kepatuhan terhadap prinsip-prinsip perikanan yang bertanggung jawab dalam pengelolaan perikanan (KKP, 2014). Untuk kasus perikanan TTC secara nasional, KKP merupakan otoritas pengelola perikanan. Adanya UU 23 tahun 2014, menuntut pengelolaan perikanan tidak hanya dipegang KKP tetapi juga pemerintah daerah tingkat I. Sinergitas kebijakan dan kelembagaan pengelolaan perikanan harus terus ditingkatkan untuk tercapainya pengelolaan perikanan tangkap berkelanjutan.

Mengingat tuna termasuk kelompok ikan beruaya jauh (highly migratory fish stocks) dan/ atau ikan beruaya terbatas diantara atau berada di Zona Ekonomi Ekslusif dari satu atau lebih negara dan laut lepas (straddling fish stocks), maka pengelolaan tuna harus dilakukan melalui kerjasama regional dan/atau Internasional. Secara nasional pengelolaan perikanan sudah dilakukan dengan Wilayah Pengelolaan Perairan (WPP), secara regional dan internasional terdapat beberapa aturan terkait pengelolaan perikanan tuna yang tertuang pada kerjasama regional dan/atau internasional, pembentukan Regional Fisheries Management Organization (RFMO), yaitu: Indian Ocean Tuna Commission (IOTC) yang mengelola tuna dan spesies seperti tuna di Samudera Hindia, Commission for The Conservation of Southern Bluefin Tuna (CCSBT) yang mengelola tuna sirip biru selatan (southern bluefin tuna), Western and Central Pacific Fisheries Commission (WCPFC) yang mengelola tuna dan spesies seperti tuna di Samudera Pasific Bagian Barat Tengah, InterAmerican Tropical Tuna Commission (IATTC) yang mengelola tuna dan spesies seperti tuna di Samudera PasifiK Bagian Timur, dan International Commission for the Conservation of Atlantic Tuna (ICCAT) yang mengelola tuna dan spesies seperti tuna di Samudera Atlantik.

Eksistensi Indonesia RFMO menjadi perhatian, mengingat kepentingan dalam penentuan alokasi kuota penangkapan tuna di wilayah Samudera Hindia dan Samudera Pasifik. 
Indonesia sebagai salah satu negara yang memiliki wilayah dan menjadi anggota penuh IOTC akan berhadapan dengan negara tidak memiliki wilayah, tetapi telah lama memanfaatkan sumber daya ikan di Samudera Hindia, seperti Jepang. Oleh karena itu, kriteria alokasi kuota yang diajukan dan strategi pemanfaatan sumber daya tuna perlu diketahui untuk memperkuat posisi Indonesia secara regional maupun internasional yang mempengaruhi keberlanjutan perikanan tuna kedepannya.

Kelembagaan nelayan berbentuk kelompok usaha bersama (KUB) menunjukkan peningkatan secara signifikan, dari 3.959 kelompok tahun 2009 menjadi 11.286 kelompok tahun 2018. Peningkatan tersebut menunjukkan adanya perubahan pola usaha masyarakat, dari berifat soliter berkembang menjadi berkelompok. Keberadaan KUB merupakan kelompok yang dibentuk nelayan berdasarkan hasil kesepakatan seluruh anggota yang dilandasi keinginan bersama untuk berusaha bersama dan dipertanggungjawabkan secara bersama guna meningkatkan pendapatan anggota. Hariadi (2011) dalam Rakhmanda, Suadi \& Supardjo (2018), menyebut kehadiran kelompok nelayan sebagai kesadaran kolektif yang didorong adanya kesamaan latar belakang sosial-ekonomi sebagai nelayan. Kesadaran kolektif tersebut diperteguh dengan kesamaan latar belakang kehidupan, sikap hidup, perasaan senasib dan sistem nilai yang dianut sehingga mendorong hampir keseluruhan anggota komunitas nelayan merespon berbagai perubahan program pembangunan dan tekanan (Satria, 2015). Kesadaran kolektif membentuk kelompok untuk meningkatkan pendapatan menjadi pijakan bersama dalam menjaga keberlanjutan sumber daya ikan sebagai mata pencahariannya.

\section{Indikator Prioritas Pengukur Pembangunan Perikanan Tangkap Berkelanjutan}

Penentuan indikator prioritas pengukur pembangunan perikanan tangkap berkelanjutan dimulai dengan kajian dari beberapa pustaka tentang indikator kinerja pembangunan secara umum. Selanjutnya dilakukan identifikasi menurut aspek ekonomi, ekologi, sosial dan kelembagaan. Indikator kinerja utama pembangunan perikanan beberapa negara di ASEAN lebih fokus pada aspek ekonomi dan ekologi, dibandingkan aspek sosial dan kelembagaan. Menurut Jennings (2005) terdapat kaitan antara indikator lingkungan dalam pengelolaan perikanan dengan melihat indikator sosial-ekonomi yang bagian dari ecosystem approach for fisheries. Pengukuran kinerja pembangunan perikanan (tangkap) sering kali menjadi perdebatan di setiap periode (rezim) dalam menilai kinerjanya karena indikator-indikator utama ditetapkan lebih difokuskan pada dimensi ekonomi semata untuk mengejar kesejahterahan sehingga tidak mencerminkan dimensi ekologis dan sosial. Indikator Kinerja Utama (IKU) perikanan tangkap yang ditetapkan selama beberapa tahun terakhir fokus ukuran kinerja pada enam IKU, meliputi pertumbuhan PDB, Nilai Tukar Nelayan (NTN), volume produksi, nilai produksi, rata-rata pendapatan Rumah Tangga Perikanan (RTP) dan rata-rata pendapatan nelayan.

Berdasarkan hasil desk study yang telah dilakukan pada kajian ini kemudian diperoleh 11 indikator utama (Tabel 2) yang mewakili aspek

Tabel 2. Penentuan Prioritas Indikator dengan Metode USG (Urgency, Seriousness, Growth).

Table 2. Determination of Priority Indicators using the USG Method (Urgency, Seriousness, Growth).

\begin{tabular}{|c|c|c|c|c|c|c|c|}
\hline No & Indikator/indicator & $\mathbf{U}$ & $\mathbf{S}$ & G & Total & $\begin{array}{l}\text { Kategori/ } \\
\text { category }\end{array}$ & $\begin{array}{l}\text { Rangking/ } \\
\text { rank }\end{array}$ \\
\hline 1 & Pertumbuhan PDB perikanan/Fisheries GDP Growth & 3,95 & 3,89 & 3,58 & 11,42 & SP & 4 \\
\hline 2 & Nilai tukar Nelayan/ Fisherman Exchange Rate & 3,68 & 3,89 & 3,68 & 11,26 & SP & 6 \\
\hline 3 & Produksi/Production & 3,89 & 4,00 & 3,74 & 11,63 & SP & 3 \\
\hline 4 & Sarpras perikanan/ Fisheries Facilities (pelabuhan/port) & 3,95 & 3,74 & 3,32 & 11,00 & SP & 8 \\
\hline 5 & Ekspor-impor/export-import & 3,74 & 3,68 & 3,47 & 10,89 & SP & 9 \\
\hline 6 & $\begin{array}{l}\text { Komoditas utama perikanan tangkap/ Main commodity capture } \\
\text { fisheries }\end{array}$ & 3,89 & 3,68 & 3,58 & 11,16 & SP & 7 \\
\hline 7 & $\begin{array}{l}\text { Kondisi perikanan tangkap skala kecil/ Small scale captured } \\
\text { fisheries }\end{array}$ & 4,32 & 4,11 & 4,00 & 12,42 & SP & 2 \\
\hline 8 & Keberlanjutan sumberdaya ikan/sustainability of fish resources & 4,47 & 4,42 & 4,26 & 13,16 & SP & 1 \\
\hline 9 & Konflik perikanan/fisheries conflict & 3,84 & 3,89 & 3,58 & 11,32 & SP & 5 \\
\hline 10 & Pengelolaan WPP/FMA management & 3,79 & 3,68 & 3,37 & 10,84 & SP & 10 \\
\hline 11 & $\begin{array}{l}\text { Kelompok usaha perikanan tangkap/ Capture fisheries } \\
\text { business group }\end{array}$ & 3,53 & 3,63 & 3,21 & 10,37 & SP & 11 \\
\hline
\end{tabular}

Keterangan Tingkat pemanfaatan (E):/Remaks on the level of utilization $(\mathrm{E})$ :

$E<0.5=$ Moderate; $0.5 \leq E<1=$ Fully-exploited; $E \geq 1=$ Over-exploited

*) Hasil pertemuan Komnas Kajiskan Juni 2019/the results of Komnas Kajiskan meeting, June 2019 
ekonomi, ekologi, sosial dan kelembagaan. Indikator ini merupakan hasil penelusuran studi dan kesepakatan yang dilakukan pada forum FGD yang kemudian dilakukan analisis prioritas terhadp indikator tersebut. Penentuan prioritas indikator yang menggambarkan kinerja pembangunan perikanan tangkap berkelanjutan dilakukan dengan menggunakan metode USG (urgency, seriousness, growth).

Berdasarkan hasil analisis USG pada Tabel 2, diketahui seluruh indikator kinerja pembangunan perikanan tangkap berkelanjutan terpilih pada penelitian ini memiliki kategori sangat prioritas. Indikator keberlanjutan sumber daya ikan menjadi indikator prioritas pertama dalam mengukur keberhasilan pembangunan perikanan tangkap berkelanjutan, diikuti indikator kondisi perikanan tangkap skala kecil dan indikator produksi. Hasil analisis ini menunjukkan bahwa kondisi sumber daya ikan dianggap memiliki pengaruh yang besar terhadap terwujudnya pembangunan perikanan tangkap berkelanjutan. Sebagai input pembangunan, sumber daya ikan menjadi sangat prioritas diperhatikan. Kebijakan perikanan berkelanjutan menjadi arus utama dalam pengelolaan perikanan tangkap di Indonesia yang semakin dihadapkan pada terbatasnya ketersediaan sumber daya ikan, bahkan di beberapa wilayah perairan laut mengalami gejala lebih tangkap. Kondisi sumber daya ikan berkaitan dengan indikator prioritas utama lainnya, seperti produksi dan kesempatan nelayan tangkap skala kecil yang memiliki keterbatasan dalam mengakses sumber daya dibandingkan nelayan dengan armada dan alat tangkap yang lebih besar, baik kapasitas maupun kemajuan teknologinya.

\section{Tantangan Pengelolaan Perikanan Tangkap Berkelanjutan di Indonesia}

Pengelolaan sumber daya ikan hendaknya mengacu UUD 1945 pasal 33 dan diatur lebih lanjut dalam UU No 45 Tahun 2009. Pengelolaan sumber daya ikan harus dilaksanakan secara terpadu dan terarah agar sumber daya tetap lestari. Code of Conduct for Responsible Fisheries dari FAO (1995) mengamanatkan pengelolaan sumber daya ikan didasarkan pada bukti-bukti data dan informasi yang terbaik (the best scientific evidence). Pengelolaan sumber daya ikan pada hakekatnya merupakan pengelolaan terhadap manusia yang memanfaatkan ikan tersebut, sehingga Rusmilyansari, Wiryawa, Haluan \& Simbolon (2010) menambahkan pengelolaan terhadap manusia merupakan pengaturan tingkah lakunya dalam pengelolaan sumber daya. Konflik perikanan tangkap sangat bervariasi antar wilayah dan antar waktu, serta bersifat multidimensional dan umumnya melibatkan berbagai pihak dalam hubungan yang kompleks. Tiga dimensi yang mempengaruhi timbulnya konflik adalah aktor, ketersediaan sumber daya dan dimensi lingkungan (Hart \& Astro 2000; Rahardjanto, 2011; Pasya, 2017).

Secara umum pengelolaan perikanan dilakukan untuk memberikan manfaat optimal dan berkelanjutan bagi masyarakat dengan tetap terjaminnya kelestarian sumber dayanya. Pengelolaan perikanan tangkap harus berbasis pada potensi sumber daya ikan dengan mempertimbangkan hukum adat dan atau kearifan lokal serta memperhatikan peran serta masyarakat. Menurut Rusmilyansari et al. (2010), pengelolaan perikanan tangkap yang cenderung tanpa batas dan lebih berorientasi kepentingan ekonomi (economic bases fisheries resource management) berakibat buruk terhadap kelangsungan pemanfaatan sumber daya ikan. Dalam situasi pemanfaatan sumber daya ikan yang serba tak terkendali, terjadi kelangkaan (scarcity) atau penipisan sumber daya ikan yang akhirnya dapat memicu terjadinya konflik pemanfaatan.

Pada pembahasan sebelumnya disampaikan bahwa untuk mewujudkan pembangunan perikanan tangkap berkelanjutan, indikator kondisi sumber daya ikan baik dari potensi dan status sumber daya ikan itu sendiri menjadi prioritas utama. Tentu saja hal tersebut harus mempertimbangkan aspek sosial budaya atau kearifan lokal dan peran serta masyarakat. Berdasarkan UU No.23 tahun 2014 diatur perluasan kewenangan provinsi, dari semula 4-12 mil laut menjadi 0-12 mil laut sehingga menghilangkan kewenangan pemerintah kabupaten/kota dalam pengelolaan wilayah laut kurang dari 4 mil. Sedangkan PP No. 54 tahun 2002 pasal 13 ayat (1) menyebutkan bahwa Gubernur atau pejabat yang ditunjuk memberikan SIUP, SIPI, dan SIKPI kepada perusahaan perikanan Indonesia yang melakukan penangkapan dan/atau pengangkutan ikan yang berdomisili di wilayah adminstrasinya. Lebih jauh dikatakan bahwa perizinan tersebut diberikan pada penggunaan kapal perikanan tidak bermotor, kapal perikanan bermotor luar, dan kapal perikanan bermotor dalam (in-board) yang berukuran di atas 10 GT 
dan tidak lebih 30 GT dan/atau yang mesinnya berkekuatan tidak lebih dari 90 Daya Kuda (DK), dan berpangkalan di wilayah administrasinya serta tidak menggunakan modal asing dan/atau tenaga kerja asing. Selanjutnya pada ayat (2) disebutkan bahwa Bupati/Walikota atau pejabat yang ditunjuk diberikan kewenangan yang sama untuk peralatan/ kapal sejenis namun berukuran tidak lebih dari 10 GT dan/atau yang mesinnya berkekuatan tidak lebih dari $30 \mathrm{GT}$.

Pengelolaan perikanan penting untuk mencegah terjadinya over exploited dan over capacity akibat lemahnya upaya pencegahan pemegang otoritas yang ditunjukkan dari terbatasnya kebijakan dan pelaksanaan dan tidak tersedianya kebijakan teknis pada aspek kebijakan pengelolaan yang berkaitan dengan konservasi dan penegakan hukum (Suharno 2018). Open access dapat terjadi pada private property sebagai konsekuensi masalah penegakan hukum (enforcement problem). Selanjutnya jika mendasarkan pada aturan perikanan berkelanjutan, maka terdapat beberapa prasyarat, yaitu: memiliki teknologi penangkapan lestari, usaha menguntungkan, dan patuh terhadap norma-norma lingkungan dengan batasan penangkapan. Suharno (2018) menambahkan dalam kebijakan pengelolaan perikanan tangkap selama ini masih diindikasikan belum efektif dalam perspektif pembangunan berkelanjutan (sustainable development), terbukti di Pantura Jawa masih banyak ditemukan pengoperasian jaring arad/ trawl meskipun sudah dilarang sejak awal 2015 (Aji, Wibowo \& Asriyanto 2015; Ermawati \& Zulyati 2015; Nababan, Solihin \& Christian 2018).

Dominasi perikanan tangkap nelayan skala kecil dan ancaman deplesi sumber daya pada komoditas utama perikanan tangkap tentu saja harus menjadi perhatian pengelolaan perikanan tangkap kedepan. Pada bahasan sebelumnya telah disampaikan bahwa perbaikan dalam pengelolaan perikanan menjadi penekanan utama untuk mewujudkan perikanan tangkap skala kecil berkelanjutan. Hal ini sejalan dengan hasil kajian Adam \& Surya (2013), bahwa untuk mencapai keberhasilan pembangunan perikanan sangat tergantung pada penentuan bentuk pengelolaan yang dilakukan secara bertanggung jawab. Pengelolaan ini di Indonesia diwujudkan dalam bentuk pengelolaan perikanan berbasis WPP. Konsep pengelolaan berbasis WPP tidak terbatas untuk perikanan tangkap saja, namun mencakup pembudidayaan ikan, konservasi, penelitian, dan pengembangan perikanan yang meliputi perairan pedalaman, perairan kepulauan, laut teritorial, zona tambahan, dan zona ekonomi eksklusif Indonesia (Permen KP No. 18 Tahun 2014). Selanjutnya dalam rangka mendukung kebijakan pengelolaan perikanan yang berkelanjutan di WPP NRI, telah ditetapkan estimasi potensi, jumlah tangkapan yang diperbolehkan dan tingkat pemanfaatan sumber daya ikan mengacu pada Kepmen KP No. 50 Tahun 2017. Estimasi jumlah potensi ikan yang dimanfaatkan adalah sebesar 12.541.438 ton, yang didalamnya mengatur status suatu WPP yang dapat dikategorikan menjadi moderate (upaya penangkapan dapat ditambah), fully-exploited (upaya penangkapan dipertahankan dengan monitor ketat), dan over-exploited (upaya penangkapan harus dikurangi). Pengelolaan perikanan tangkap berbasis WPP dalam pelaksanaannya tidak terlepas dari komplesitas yang dihadapi dan harus didukung dengan berbagai perlengkapannya baik dari aspek fisik maupun kelembagaannya.

\section{KESIMPULAN DAN REKOMENDASI KEBIJAKAN}

\section{Kesimpulan}

Berdasarkan hasil kajian dapat disimpulkan bahwa perikanan tangkap di Indonesia meskipun memberikan manfaat secara ekonomi, namun belum merata dirasakan para pelakunya. Hal ini ditunjukkan dari struktur perikanan tangkap yang masih di dominasi nelayan skala kecil yang selalu di identikkan dengan kemiskinan. Dari sisi pembangunan perikanan tangkap berbasis komoditas utama TTC, diketahui bahwa komoditas TTC memberikan kontribusi yang besar terhadap produksi perikanan tangkap nasional dan permasalahan IUUF menjadi ancaman utama terhadap keberlanjutannya. Hasil tangkapan TTC yang lebih banyak dihasilkan nelayan skala kecil menjadi tantangan terhadap keberlanjutan TTC skala kecil karena adanya kompetisi antara pelaku usaha skala kecil dengan skala industri.

Kondisi perikanan tangkap jika dilihat dari aspek ekologi, ancaman IUUF memberikan tekanan besar terhadap keberlanjutan sumber daya dan pada akhirnya mengakibatkan deplesi terhadap sumber daya ikan. Untuk WPP yang berada pada status tingkat pemanfaatan over exploited menjadi prioritas utama peningkatan luas kawasan konservasinya. Selanjutnya untuk 
aspek ekonomi, faktor modal dan investasi usaha menjadi tantangan dalam mewujudkan perikanan tangkap berkelanjutan. Hal tersebut dilakukan untuk meningkatkan kapabilitas nelayan skala kecil baik dari sisi teknologi dan armada. Perikanan tangkap skala kecil tetap menjadi perhatian utama untuk mewujudkan perikanan tangkap berkelanjutan karena dominasinya dan merupakan penerima manfaat yang sangat besar. Secara sosial, kondisi perikanan tangkap di Indonesia tidak terlepas dari konflik, baik konflik antar nelayan lokal maupun dengan nelayan asing. Namun sejak diberlakukannya moratorium kapal eks asing dan peningkatan pengawasan sumber daya perikanan, khususnya di wilayah perbatasan RI, jumlah konflik dengan nelayan asing sudah jauh berkurang. Selanjutnya, terkait aspek kelembagaan dalam mewujudkan perikanan tangkap berkelanjutan diperlukan sinergitas kebijakan dan kelembagaan pengelolaan perikanan harus terus ditingkatkan untuk tercapainya pengelolaan perikanan tangkap berkelanjutan. Keterlibatan Indonesia dalam pengelolaan perikanan di tingkat global seperti RFMO dan IOTC menjadi hal yang sangat penting untuk di perhatikan hal ini mengingat kepentingan Indonesia dalam menentukan alokasi kuota tangkapan tuna yang menjadi komoditas utama perikanan tangkapnya. Pembentukan lembaga atau kelompok nelayan di tingkat mikro menjadi perhatian utama untuk memperkuat posisi nelayan skala kecil.

Hasil analisis USG menunjukkan bahwa 11 indikator utama pengukur keberhasilan pembangunan perikanan tangkap berkelanjutan yang telah disusun memiliki status sangat prioritas. Indikator kondisi sumber daya ikan dan kondisi perikanan tangkap skala kecil menjadi prioritas utama. Kedua indikator tersebut berkaitan dengan indikator lainnya seperti produksi dan kesempatan nelayan tangkap skala kecil yang memiliki keterbatasan dalam mengakses sumber daya dibandingkan nelayan dengan armada dan alat tangkap yang lebih besar. Perbaikan terhadap pengelolaan perikanan menjadi faktor penentu keberhasilan pembangunan perikanan tangkap berkelanjutan. Pengelolaan perikanan tangkap harus berbasis pada potensi sumber daya ikan harus mempertimbangkan kearifan lokal dan peran serta masyarakat. Konsep pengelolaan perikanan berbasis WPP harus didukung dengan berbagai perlengkapannya baik dari aspek fisik maupun kelembagaannya.

\section{Rekomendasi Kebijakan}

Berdasarkan uraian diatas, maka rekomendasi kebijakan untuk mewujudkan keberlanjutan perikanan tangkap di Indonesia, yaitu: (1) pengelolaan sumber daya ikan harus didasarkan kondisi sumber daya ikan baik dari potensi dan status pemanfaatannya. Pengelolaan terhadap nelayan skala kecil menjadi hal penting dilakukan mengingat dominasinya yang besar dan memberikan tekanan yang besar terhadap sumber daya. Pengelolaan nelayan skala kecil dapat dilakukan dengan meningkatkan kapabilitasnya melalui kemudahan akses modal dan peningkatan investasi usaha; (2) Pengelolaan sumber daya ikan berbasis WPP melalui penguatan kelembagaan dan dukungan sarana fisik dapat menjadi salah satu cara pengelolaan sumber daya ikan untuk mencapai tujuan kesejahteraan pelaku, dan keberlanjutan usaha serta sumber daya; (3) Optimalisasi pengelolaan perikanan tangkap melalui pendekatan input (alat tangkap) dapat dilakukan melalui penggunaan alat tangkap yang memiliki produktivitas tinggi, efektif dan memiliki selektifitas tinggi, disamping melakukan modernisasi armada dari aspek kelengkapan teknologi dan peningkatan ukuran armada menjadi lebih dari 30 GT karena mayoritas armada di Indonesia masih didominasi armada penangkapan skala kecil atau berukuran kurang dari $10 \mathrm{GT}$; dan (4) Kebijakan terkait pengelolaan sumber daya ikan berkelanjutan menjadi prioritas utama untuk mewujudkan pembangunan perikanan tangkap berkelanjutan di Indonesia.

\section{UCAPAN TERIMA KASIH}

Penulis mengucapkan terima kasih kepada Kepala Badan Riset dan SDM Kelautan dan Perikanan atas kesempatan studi dan melakukan penelitian. Penulis juga mengucapkan terima kasih kepada para pihak yang telah membantu mewujudkan karya tulis ini. Ucapan terimakasih juga disampaikan pada segenap tim redaksi Jurnal Sosial Ekonomi Kelautan dan Perikanan yang telah membantu menyempurnakan tulisan ini.

\section{DAFTAR PUSTAKA}

Adam L. \& Surya T.A. (2013). Kebijakan Pengembangan Perikanan Berkelanjutan di Indonesia. Jurnal Ekonomi \& Kebijakan Publik, Vol 4 (2) : 195-211

Adhuri DS, Wahyono A \& Indrawasih R. (2005). Fishing in, Fishing out : Memahami Konflik-Konflik Kenelayanan di Kalimantan Timur dan Nusa Tenggara Timur. Ed ke-1. Jakarta : LIPI Press. 
Aji IN, Wibowo BA \& Asriyanto. (2015). Analisis Faktor Produksi Hasil Tangkapan Alat Tangkap Cantrang di Pangkalan Pendaratan Ikan Bulu Kabupaten Tuban. Journal Fisheries Resources Utilization Management and Technology, Vol 2 (4) : 50-58.

[BAPPENAS] Badan Perencanaan Pembangunan Nasional. (2014). Kajian Strategi Pengelolaan Perikanan Berkelanjutan. Direktorat Kelautan dan Perikanan, Kementerian PPN/BAPPENAS. Jakarta

Beddington JR, Agnew JR \& Clark CW. (2007). Current Problems in the Management of Marine Fisheries. Science 316. Pp : 1713-1716

Bene C. \& Tewfik A. (2001). Fishing Effort Allocation and Fishermen's Decision Making Process in a Multi-Species SmallScale Fishery: Analysis of the Conch and Lobster Fishery in Turks and Caicos Islands. Human Ecology. 29(2): 157186.

Bene C, Macfadyen G \& Allison EH. (2007). Increasing the Contribution of Small-Scale Fisheries to Poverty Alleviation and Food Security. FAO Fisheries Technical Paper 481. Rome: FAO

Cunningham S. (1993). Fishermens' Incomes and Fisheries Management. Research Paper No. 61. Portsmouth: CEMARE. University of Portsmouth. Dradjat, F.M., 2004. Bioekonomi Udang Karang (Panulirus spp.) pada Usaha Perikanan Tangkap Skala Kecil di Kabupaten Icebumen dan Sekitarnya (Doctoral dissertation, Program Pendidikan Pasca sarjana Universitas Diponegoro)

Elo S, Kääriäinen M, Kanste O, Pölkki T, Utriainen K \& Kyngäs H. (2014). Qualitative content analysis: A focus on trustworthiness. SAGE open, 4(1), p.2158244014522633.

Ermawati N \& Zuliyati. (2015). Dampak Sosial dan Ekonom Atas Peraturan Menteri Kelautan dan Perikanan Nomor 2/PER MEN-KP/2015 (Studi Kasus Kecamatan Juwana Kabupaten Pati). Prosiding Seminar Nasional Multi Disiplin IImu. ISBN 978-979-3649-81-8.

[FAO] Food \& Agriculture Organization. (2009). FAO Tehcnical Guidelines For Responsible Fisheries. Fisheries Management. Food and Agriculture Organization of the United Nations. Rome (Ita) : FAO

[FAO] Food \& Agriculture Organization. (2018). Fishery and Aquaculture Statistics 2016. Roma, Italia.

Fauzi A \& Anna Z. (2002). Penilaian Depresiasi Sumber daya Perikanan Sebagai Bahan Pertimbangan Penentuan Kebijakan Pembangunan Perikanan. Jurnal Pesisir dan Lautan, Volume 4. No 2. 2002 : 36 - 49 Bogor: Pusat Kajian Sumber daya Pesisir dan Lautan. Institut Pertanian Bogor (ID): Institut Pertanian Bogor.

Fauzi A. (2005). Kebijakan Perikanan dan Kelautan: Isu, Sintesis, dan Gagasan. Gramedi Pustaka Utama,
Jakarta, hlm 135-136.

Fauzi A. (2010). Ekonomi Perikanan "Teori, Kebijakan dan Pengelolaan". Jakarta (ID): PT Gramedia Pustaka Utama.

Firdaus M, Fauzi A, Falatehan AF. (2018). Deplesi Sumber Daya Ikan Tuna dan Cakalang di Indonesia. Jurnal Sosial Ekonomi Kelautan dan Perikanan, Vol 13 No. 2. Jakarta

Firdaus M. (2018). Neraca Sumber Daya Ikan Tuna dan Cakalang di Indonesia. Thesis. Tidak Dipublikasikan. Bogor : Sekolah Pascasarjana - Institut Pertanian Bogor.

Firdaus M. (2018). Profil Perikanan Tuna dan Cakalang di Indonesia. Buletin IImiah Marina Sosial Ekonomi Kelautan dan Perikanan, Vol 4. No 1 Tahun 2018. Jakarta.

Gallic BL. (2002). Fisheries Sustainability Indicators: The OECD Experience. Joint workshop EEA-EC DG Fisheries-DG Environment on "Tools for measuring (integrated) Fisheries Policy aiming at sustainable ecosystem" October 28-29, 2002, Brussels (Belgium)

Garcia SM, Zerbi A \& Aliaume C, Do Chi T, Lasserre G. (2003). The Ecosystem Approach To Fisheries. Issues. Terminology Principles. Institutional Foundations. Implementation And Out-Look. FAO Fisheries Technical Paper. 443. 71 pp.

Hariadi SS. (2011). Dinamika Kelompok: Teori dan Aplikasinya untukAnalisis Keberhasilan Kelompok Tani sebagai Unit Belajar, Kerjasama, Produksi, dan Bisnis. Yogyakarta: Sekolah Pascasarjana Universitas Gadjah Mada

Hart N \& Castro P. (2000). Conflict and Natural Resource Management. Rome: FAO. 79p. Hopkins, D.J. and King, G., 2010. A method of automated nonparametric content analysis for social science. American Journal of Political Science, 54(1), pp.229-247.

Hopkins DJ \& King G. (2010). A method of automated nonparametric content analysis for social science. American Journal of Political Science, 54(1), pp.229-247.

Hsieh HF \& Shannon SE. (2005). Three Approaches to Qualitative Content Analysis. Qualitative Health Research. 15(9). pp.1277-1288

Huang S \& He Y. (2019). Management of China's Capture Fisheries : Review and Prospect. Journal Aquaculture and Fisheries, Vol 4 (2019) : 173-182

Husnayain A, Artanti KD \& Zaenal A. (2015). Analisis Sistem Surveilans Epodemologi Molekuler Virus Dengeu di BBTKLL PP Surabaya Tahun 2012-2014. Jurnal Berkala Epidemiologi, Vol 3 (2) : 146-157.

Jamal M, FA. Sondita, B. Wiryawan \& J. Haluan. (2014). Konsep Pengelolaan Perikanan Tangkap 
Cakalang (Katsuwonus pelamis) di Kawasan Teluk Bone dalam Perspektif Keberlanjutan. Jurnal IPTEKS PSP, Vol 1 (2) : 196-207.

Jennings S. (2005). Indicators to support an ecosystem approach to fisheries. Fish and Fisheries, 6, 212-232

Lieng SN, Yagi N, A. Mori \& J. Hastings. (2018). Savings-Group Improvements Contribute to Sustainable Community-Fisheries Management: A Case Study in Cambodia. Sustainability; 10(8):2905

Loeb S, Dynarski S, McFarland D, Morris P \& Reardon S. (2017). Descriptive analysis in education: A guide for researchers (NCEE 2017-4023). Washington, DC: U.S. Department of Education, Institute of Education Sciences, National Center for Education Evaluation and Regional Assistance.

Machena C \& Kwaramba R. (1997). The Creation of Property Rights to Promote Sustainable Development in Lake Kariba Inshore fishery in Zimbabwe. In K. Remane (Ed.). African Inland Fisheries, Aquaculture and the Environment (pp. 245-254). London: Fishing News Books.

Mamuaya GE, Haluan J, Wisudo SH \& Astika IW. (2007). Status Keberlanjutan Perikanan Tangkap Di Daerah Kota Pantai: Penelaahan Kasus Di Kota Manado (the Status of Sustainable Capture Fisheries in Coastal City Region: Case Study for Manado City). Buletin PSP, 16(1), pp.64-78.

Martono N. (2010). Metode Penelitian Kuantitatif: Analisis Isi dan Analisis Data Sekunder (sampel halaman gratis). RajaGrafindo Persada

Nababan BO, Solihin A \& Christian Y. (2018). Dampak Sosial Ekonomi Kebijakan Larangan Pukat Hela dan Pukat Tarik di Pantai Utara Jawa. Indonesia Marine Fellows Program - MFP. Riset Ekonomi Terapan dalam Pengelolaan Perikanan dan Konservasi. CSF dan IPB. Jakarta.

Nizar M. (2015). Analisis Keberlanjutan Usaha Budidaya Rumput Laut Pada Penerima Palet Bantuan Langsung Masyarakat di Kabupaten Muna. Tesis. Program Pasca Sarjana Universitas Terbuka. http://repository.ut.ac.id/ 6971/1/42768.pdf.

Nova SAR. (2017). Illegal, Unreported and Unregulated Fishing : The Impacts and Policy For Its Completion in Coastal West of Sumatera. Jurnal Hukum Internasional, Vol 14 (2) : 237 - 250.

Pasya G. (2017). Penanganan Konflik Lingkungan. Gramedia Pustaka Utama. Jakarta

Peraturan Menteri Kelautan dan Perikanan Republik Indonesia Nomor: 18/Permen-KP/2014, tentang Wilayah Pengelolaan Perikanan Negara Republik Indonesia. Berita Negara Republik Indonesia Nomor 17

Peraturan Pemerintah No. 32 Tahun 2019, tentang Rencana Tata Ruang Laut. Jakarta. Lembaran
Negara Republik Indonesia Tahun 2019 Nomor 89

Peraturan Pemerintah No. 54 Tahun 2002, tentang Usaha Perikanan. Tambahan Lembaran Negara Republik Indonesia Nomor 4230.

Purnomo BH. (2012). Peranan Perikanan Tangkap Berkelanjutan untuk Menunjang Ketahanan Pangan di Indonesia. Artikel. Fakultas Teknologi Pertanian Universitas Jember.

Rahardjanto AK. (2011). Studi Pendahuluan Model Pengelolaan Sumber daya Aur Partisipatif Akomodatif Guna Antisipasi Konflik Pembagian Air (Kasus Sumberawan Kecamatan Singosari Malang). Jurnal Salam 13(2).

Rakhmanda A, Suadi \& Supardjo SD. (2018). Peran Kelompok Nelayan Dalam Perkembangan Perikanan di Pantai Sadeng Kabupaten Gunungkidul. Jurnal Sosiologi Pedesaan, Vol. 6, hal 94-104

Rizal A, Iskandar, Herawati H, Dewanti LP. (2018). Potret dan Review: Strategi Pembangunan Perikanan dan Kelautan. Unpad Press. Bandung.

Rusmilyansari, Wiryawa B, Haluan J, Simbolon D. (2010). Model Pengelolaan Sumber daya Perikanan Tangkap Berbasis Konflik. Marine Fisheries, 1 (1): 65-75

Sanger CLM, Jusuf A \& Andaki JA. (2019). Analisis Orientasi Kewirausahaan Nelayan Tangkap Skala Kecil dengan Alat Tangkap "JUBI" di Kelurahan Batulubang Kecamatan Lembeh Selatan Kota Bitung. Akulturasi: Jurnal IImiah Agrobisnis Perikanan, Vol 7 (1) : 1095-1101

Satria A. (2015). Pengantar Sosiologi Masyarakat Pesisir. Jakarta: Yayasan Pustaka Obor Indonesia.

Sibagariang OP, Fauziyah, Agustriani F. (2013). Analisis Potensi Lestari Sumber daya Perikanan Tuna Longline di Kabupaten Cilacap. Jawa Tengah. Maspari Journal, Vol 03 (2011) 24-29. PS IImu Kelautan FMIPA UNSRI.

Soekanto S. (2002). Sosiologi Suatu Pengantar. Jakarta. PT. Raja Grafindo Persada

Solihin A. (2010). Politik Hukum Kelautan dan Perikanan: Isu, Permasalahan, dan Telaah Kritis Kebijakan. Nuansa Aulia.

Sowman M \& Bergh M. (2006). Economic, Social and Environmental Impacts of IUU Fishing in Africa. Action Plan. Advocacy Paper. 10.13140/ RG.2.2.32415.15528.

Suharno TW. (2018). Kebijakan Pengelolaan Usaha Perikanan Tangkap Nelayan Skala Kecil Di Pantura Jawa Tengah. Prosiding Seminar Nasional Multi Disiplin IImu \& Call For Papers Unisbank. Semarang.

Sularso A. (2005). Alternatif Pengelolaan Perikanan Udang di Laut Arafura. Disertasi (Tidak Dipub- 
likasikan). Sekolah Pascasarjana Institut Pertanian Bogor. Bogor, 130.

Surat Edaran Menteri Tenaga Kerja RI No. SE-07/ MEN/1990, tentang Pengelompokan Upah.

Syahrani DA, MA. Musadieq \& A. Darmawan. (2017). Analisis Peran Kebijakan Illegar. Unreported and Unregulated Fishing (IUU) Pada Ekspor Ikan Tuna dan Udang Tangkap (Studi pada sebelum dan sesudah penerapan Permen KP nomor 56 dan 57/ PERMEN KP 2014 terhadap Volume Ekspor Tuna dan Udang Tangkap di Jawa Timur). Jurnal Administrasi Bisnis JAB), Vol 45 No 1 (2017). Fakultas Administrasi dan Bisnis. Universitas Brawijaya. Malang.

Triarso I. (2012). Potensi dan Peluang Pengembangan Usaha Perikanan Tangkap di Pantura Jawa Tengah. Jurnal Saintek Perikanan, Vol 8 (1) : 65 -73 .

Uktolseja JCB. (1987). Estimated Growth Parameters and Migration of Skipjack Tuna Katsuwonus pelamis in The Eastern Indonesian Water Through Tagging Experiments. Jakarta : Jurnal Penelitian Perikanan Laut, No. 43 Tahun 1987. Balai Penelitian Perikanan Laut. Hal. 15-44.

Undang-Undang No. 23 Tahun 2014, tentang Yang Mengatur Tentang Pemerintahan Daerah. Tambahan Lembaran Negara Republik Indonesia I Nomor 5587. Tahun 2014. Jakarta.

Undang-Undang No. 7 Tahun 2016, tentang Yang Mengatur Tentang Perlindungan dan Pemberdayaan NeMalayan, Pembudidaya Ikan, dan Petambak Garam. Tambahan Lembaran Negara Republik Indonesia Nomor 5870I Tahun 2016. Jakarta

Undang-Undang Nomor 31 Tahun 2004, tentang Perikanan, Lembaran Negara Republik Indonesia Tahun 2004 Nomor 118, Tambahan Lembaran Negara Republik Indonesia Nomor 4433, sebagaimana telah diubah dengan Undang-Undang Nomor 45 Tahun 2009, tentang Perubahan atas Undang-Undang Nomor 31 Tahun 2004, tentang Perikanan. Lembaran Negara Republik Indonesia Tahun 2009 Nomor 154. Tambahan Lembaran Negara Republik Indonesia Nomor 5073.

Waluyo B S. (2009). Kajian Potensi Perikanan Tangkap dan Pertumbuhan Jumlah Kapal Tangkap (Purse Seine) di Kabupaten Pekalongan. Jurnal Kapal, Vol 6 (2) : 134-137.

Widodo S. (2009). Strategi Nafkah Rumah Tangga Nelayan dalam Menghadapi Kemiskinan. Jurnal Kelautan. Vol. 2 No 2: 150-157
Wijaya RA, HM. Huda \& Manadiyanto. (2012). Penguasaan Aset dan Struktur Pembiayaan Usaha Penangkapan Ikan Tuna Menurut Musim Yang Berbeda. Jurnal Sosial Ekonomi Kelautan dan Perlkanan, Vol 7 No 2 (2012). Pusat Penelitian Sosial Ekonomi Kelautan dan Perlkanan. Jakarta.

Wiyono ES. (2014). Optimizing purse seine fishing operations in the Java Sea, Indonesia. Aquaculture, Aquarium, Conservation \& Legislation, 7 (6), pp.475-482. 
Lampiran 1. Luasan Kawasan Konservasi Perairan dan Kawasan Konservasi Pesisir dan Pulau-Pulau Kecil Daerah Indonesia di 11 WPP, Tahun 2003-2017.

Appendix 1. Extent of Marine Protected Areas and Coastal Conservation Areas and Indonesian Small Islands in 11 FMA, 2003-2017)

\begin{tabular}{cc}
\hline WPP/FMA & Luasan/Area (ha) \\
\hline 571 & $41,982.20$ \\
572 & $758,914.82$ \\
573 & $669,419.82$ \\
711 & $2,768,161.16$ \\
712 & $185,048.13$ \\
713 & $450,727.95$ \\
714 & $1,899,645.18$ \\
715 & $1,700,504.26$ \\
716 & $586,336.58$ \\
717 & $46,983.62$ \\
718 & $9,107,723.71$ \\
\hline
\end{tabular}

Sumber/Source: KKP 2019 